\title{
A Universal Digital Library Based on Unimpeded Access (and Some Proposals Based on Information Ethics)
}

\author{
George Bouchagiar ${ }^{1}$ \\ ${ }^{1}$ Institute for Information Law (IViR), Amsterdam, The Netherlands \\ Correspondence: George Bouchagiar, Institute for Information Law (IViR), Amsterdam, The Netherlands.
}

Received: July 27, 2018 Accepted: August 10, 2018 Online Published: August 27, 2018

doi:10.5539/res.v10n4p33

URL: https://doi.org/10.5539/res.v10n4p33

\begin{abstract}
Massive amounts of digital information, ready to be shared without any restrictions, could mean that what we are dealing with today is a universal collection of all knowledge that is freely available to everyone. However, information is consumed as a commodity and is, thus, locked up behind pay-walls set up by firms. But knowledge should not be privatized and information should be used as a tool to achieve goals of benevolence. This paper examines whether we have the technologies to move towards an ideal direction, where a Universal Digital Library would be introduced to ensure unimpeded access to the sum of all knowledge. It points out that there are both the necessary technologies and models to achieve this, albeit legal obstacles prevent people from accessing knowledge. This renders the scenario of the above imaginary library a utopia. So, more realistic approaches are discussed to support that current libraries, whether physical or digital, can very well perform their role as equalizers of access to knowledge. Finally, conclusions are drawn and optimistic scenarios are submitted to argue that law could someday make such universal-library-utopia come true.
\end{abstract}

Keywords: Universal Digital Library, unimpeded access, information ethics, digital divide

\section{Introduction}

Books are for use: every reader should have the right to get her book, while every book should "have the right to find its reader". Applying the above traditional "laws" to the digital environment could mean "information is for use: every user should have the right to get her information, while every item of information should have its recipient". This could be further translated into letting digital "shelves" open by abolishing costs for subscriptions, broadening unimpeded access to information, and making it easier than ever to receive information.

Unimpeded access to information is an old subject of scientific discussion ${ }^{2}$ and, whether open ${ }^{3}$ or free ${ }^{4}$, has been strongly

\footnotetext{
${ }^{1}$ As some have put it, no paper related to the values of librarianship could begin without summarizing the Five Laws of Library Science introduced in 1931 by Ranganathan: Books are for use; For every reader, his or her book; For every book, its reader; Save the time of the reader; A library is a growing organism. See Foster Catherine, McMenemy David, Do librarians have a shared set of values? A comparative study of 36 codes of ethics based on Gorman's Enduring Values, in Journal of Librarianship and Information Science, Vol. 44, Issue 4, 2012, pp. 249-262 (available at http://journals.sagepub.com/doi/10.1177/0961000612448592), at p. 250; Ranganathan Siyali Ramamrita, The Five Laws of Library Science, 1931, Madras Library Association.
}

2 In 1942, Merton spoke of the four principles (often referred to as CUDOS or "Merton Thesis") that have to govern science: Communalism, meaning common ownership over scientific discoveries; Universalism, in the sense that claims with regard to scientific truth should be based on universally accepted criteria independent of race, religion or other distinctions; Disinterestedness, meaning that scientists should be awarded when acting in selfless ways; Organized Skepticism, i.e. all scientific ideas should be subject to substantiated scrutiny by the scientific community. See Merton Robert, The normative structure of science, in The Sociology of Science: Theoretical and Empirical Investigation, University of Chicago Press, 1942, pp. 267-278 (originally published as "Science and Technology in a Democratic Order", in Journal of Legal and Political Sociology I, 1942, pp. 115-126; also published as "Science and Democratic Social Structure", in Merton Robert, Social Theory and Social Structure). Available at

https://www.collier.sts.vt.edu/5424/pdfs/merton_1973.pdf. See also Papadopoulos Marinos, From CUDOS and Semion to Creative Commons and Open Knowledge Foundation, in Bottis Maria (ed.), The history of Information: From papyrus to the electronic document, Nomiki Bibliothiki S.A., 2014, pp. 273-282, at pp. 273-274.

${ }^{3}$ See, amongst others, Scheufen Marc, Copyright Versus Open Access, On the Organization and International Political 
supported not only by scholars but also by libraries ${ }^{5}$, society's last non-commercial meeting places ${ }^{6}$. Scholars have submitted several opinions on guiding principles and values of librarianship and most of them mention intellectual freedom, privacy, confidentiality, intellectual property ${ }^{7}$ rights, neutrality, preservation of culture, and equity of access ${ }^{8}$.

Economy of Access to Scientific Knowledge, 2015, Springer International Publishing Switzerland. In accordance with the Budapest Open Access Initiative (BOAI), open access means free and unrestricted online availability of scientific literature. In this context, literature should be freely accessible, meaning that users should be enabled to read, download, copy, distribute, print, search, or use such literature for any purpose, without financial, legal, or technical barriers, other than those of gaining access to the Internet itself. See strategies recommended by BOAI, with regard to self-archiving and open-access journals, at http://www.budapestopenaccessinitiative.org/read. See also Guédon Jean-Claude, Open Access: Toward the Internet of the Mind, 2017, available http://www.budapestopenaccessinitiative.org/boai15/Untitleddocument.docx. As some authors have observed, potential efficiency gains from open access and zero-profit ownership are greater as advances in technology reduce the costs of delivering information to consumers. Campbell James, Ownership and pricing of information: A model and application to open access, Information Economics and Policy, Vol. 33, 2015, pp. 29-42, at p. 29 (mentioning that "[...] Information is overpriced and underused under both monopoly and zero-profit ownership, and underpriced and overused under open access [...] However, as the costs fall towards zero, outcomes under zero-profit ownership and open access both tend towards the efficient level, and for-profit monopoly ownership is increasingly inefficient [...]").

${ }^{4}$ See Stallman Richard, Free software, Free society, Selected Essays of Richard M. Stallman, 2002, Free Software Foundation (edited by Joshua Gay). With regard to software, as Stallman points out, free use, processing and distribution shall mean free as in "freedom", not free as in "free beer". Stallman speaks of four freedoms: Freedom 0 that is the freedom to run the program for any purpose; Freedom 1, which refers to the freedom to study how the program works and adapt it to one's needs; Freedom 2 that means freedom to redistribute copies; Freedom 3, which is the freedom to improve the program for the benefit of the community. See Stallman Richard, id, at pp. 43, 165. As Stallman puts it, "[...] If anything deserves reward, it is social contribution [...] If programmers deserve to be rewarded for creating innovative products, by the same token they deserve to be punished if they restrict the use of these programs [...]" (Stallman Richard, id, at p. 38).

5 Traditionally, a library is a place in which books, manuscripts, or literary and artistic materials are kept for use -but not for sale. See Warr Hanadashisha, Open Source Digital Library Software: A Literature Review, in Proceedings of the National Seminar on "Preservation and Conservation of Information Resources in Knowledge Society: Issues, Challenges and Trends”, pp. 238-258, Manipur University, Canchipur, Imphal, March 3-4, 2009 (available at SSRN: https://ssrn.com/abstract=1639383 or http://dx.doi.org/10.2139/ssrn.1639383), at p. 238 (with further references). Today, a digital library can be understood as an environment that brings together "collections, services, and people in support of the full life cycle of creation, dissemination, use, and preservation of data, information, and knowledge". See Kapidakis Sarantos, Introduction to Digital Libraries, Disigma Ed., $2^{\text {nd }}$ Edition, 2014, at p. 84 (with further references). See also Fogarty Vivianne, Libraries and Human Rights, Working Together to Reach Our Full Potential, in Perspectives on Libraries as Institutions of Human Rights and Social Justice (published online: 26 Feb 2016; pp. 71-90, available at https://doi.org/10.1108/S0065-283020160000041004), at p. 72 (mentioning that the library is a room full of resources that people can borrow or look at).

${ }^{6}$ Danish Agency for Libraries and Media, The Public Libraries in the Knowledge Society, Summary from the Committee on Public Libraries in the Knowledge Society, 2010, at p. 7 (available at https://slks.dk/fileadmin/publikationer/publikationer_engelske/Reports/The_public_libraries_in_the_knowledge_society ._Summary.pdf). As others have claimed, libraries symbolize society's best idea about itself. See Conner Matthew, The new university library: four case studies, Chicago, ALA Editions, 2014, at p. 148.

${ }^{7}$ Intellectual Property refers to intangible interests in commercially valuable products of the human intellect. See Garner Bryan, Black's Law Dictionary, $10^{\text {th }}$ Edition, 2014, Thomson West. The interests are intangible, meaning that one does not possess intellectual property in the same way as one possesses tangible property, such as land or a chair. See Melamed Douglas, Picker Randal, Weiser Philip, Wood Diane, Antitrust Law and Trade Regulation, Cases and Materials, $7^{\text {th }}$ Edition, 2018, Foundation Press, at p. 891.

${ }^{8}$ Koehler C. Wallace, Hurych M. Jitka, Dole V. Wanda \& Wall Joanna, Ethical Values of Information and Library Professionals, An expanded Analysis, Intl. Inform. \& Libr. Rev. 2000, Vol. 32, pp. 485-507, at p. $486-487$ (with further references), doi:10.1006/iilr.2000.0141, available at

https://www.sciencedirect.com/science/article/pii/S1057231700901413. See also Foster Catherine, McMenemy David, Do librarians have a shared set of values?, id; Sturges Paul, Remember the human: the first rule of netiquette, librarians 
Focusing on intellectual freedom, meaning the right of every individual to both seek and receive information from all points of view without restriction ${ }^{9}$, it would be fair to claim that, today, innumerous items of information are ready to be shared without any barriers. This has turned everyone into a "digital librarian" and, when everyone is a librarian ${ }^{10}$, then library is everywhere ${ }^{11}$. So, have we created a universal library, where information is freely available to anyone? Have we achieved the ideal goal of global information justice, where information technologies and knowledge are used to free humanity from struggles over scarce resources and enhance human identity within the community? Have we moved from "liberty, equality, fraternity" to "rip, burn, and mix" or even better to "copy, use, and share"?

Today, information is consumed as a commodity rather than being used as a tool for personal growth or development of democratic societies ${ }^{12}$. So, we have not yet achieved the above goals, for which many scientists (or, to some, "hacktivists") fought in the past ${ }^{13}$. But information's moral character is of crucial concern and, thus, information should be regarded as something more than an asset ${ }^{14}$. In this context, information and knowledge should be freely circulated for the benefit of humanity, rather than privatized in favor of firms' interests.

Given the above ethical issues, this paper examines the potential to move towards an ideal Universal Digital Library that would allow unimpeded ${ }^{15}$ access to information. After observing that there is the technology to achieve this, but several

and the Internet, Online Information Review, Vol. 26, Issue 3, pp. 209-216 (available at https://www.emeraldinsight.com/doi/full/10.1108/14684520210432486); International Federation of Library Associations and Institutions (IFLA) Code of Ethics for Librarians and other Information Workers, where the following principles are mentioned: access to information (Clause 1), responsibilities towards individuals and society (Clause 2), privacy, secrecy and transparency (Clause 3), open access and intellectual property (Clause 4), neutrality, personal integrity and professional skills (Clause 5), and colleague and employer/employee relationship (Clause 6). Available at https://www.ifla.org/publications/node/11092. It is worth mentioning that because computer laws did not exist in the past, professional organizations initiated their own ethical codes. Suduc Ana-Maria, Bizoi Mihai, Gheorghe Filip, Ethical Aspects on Software Piracy and Information and Communication Technologies Misuse, in IFAC Proceedings Volumes, Vol. 42, Issue 25, January 2009, pp. 30-35, at p. 30 (available at

https://www.sciencedirect.com/science/article/pii/S1474667015300082); Oz Effy, Ethical Standards for Information Systems Professionals: A Case for a Unified Code, MIS Quarterly, Vol. 16, No. 4, 1992, pp. 423-433, observing that, unlike other occupational groups, such as lawyers, Information Technology (IT) professionals did not have a common ethical code.

${ }^{9}$ See definition provided by American Library Association (ALA). Available at http://www.ala.org/advocacy/intfreedom/censorship/faq\#ifpoint1. See also Article 19 of the Universal Declaration of Human Rights (UDHR): "[...] Everyone has the right to freedom of opinion and expression; this right includes freedom to hold opinions without interference and to seek, receive and impart information and ideas through any media and regardless of frontiers [...]".

${ }^{10}$ Perhaps, today's "librarians" are not the ones, of whom Chambers and Myall spoke many years ago ("[...] The librarian I know best is plump, dowdy, with glasses, and her hair in a bun-but she runs a library that provides vital services to an appreciative clientele, in an atmosphere of sharing, accommodation, and frequent laughter. Her aim is not 'power lunches', but empowerment, both of library personnel and clientele [...]"). Chambers Sydney \& Myall Carolyne, Women \& the Values of American Librarianship, Las Collinas, Ide House, 1994, at p. 58 (citing Carol M. Spawn).

${ }^{11}$ Memory of the World, Librarian: End-to-end catalog, 2012, available at https://www.memoryoftheworld.org/blog/2012/11/26/end-to-end-catalog-2/.

${ }^{12}$ Koelman J. Kamiel, The Public Domain Commodified: Technological Measures and Productive Information Use, in L. Guibault and P. B. Hugenholtz (eds), The Future of the Public Domain, Identifying the Commons in Information Law, 2006, Kluwer Law International, pp. 105-119, at p. 105.

${ }^{13}$ See Swartz Aaron, Guerilla Open Access Manifesto, July 2008, available at https://archive.org/stream/GuerillaOpenAccessManifesto/Goamjuly2008_djvu.txt; Bodó Balázs, Libraries in the post-scarcity era, in Porsdam (ed.), Copyrighting Creativity: Creative values, Cultural Heritage Institutions and Systems of Intellectual Property, Ashgate, 2015 (available at https://ssrn.com/abstract=2616636 or http://dx.doi.org/10.2139/ssrn.2616636), at p. 2, mentioning that book piracy is a story about how knowledge is circulated beyond and often against the structures of political and economic power.

${ }^{14}$ Smith Martha, Information ethics, in Advances in Librarianship, Vol. 25 (published online 09 Mar. 2015), pp. 29-66, at p. 42. Available at https://doi.org/10.1016/S0065-2830(01)80019-2.

${ }^{15}$ The term "unimpeded" is used in this paper to refer to access to information and knowledge without any economic, 
barriers do not allow people to reach this utopia anytime soon, a more realistic approach, based on Information Ethics ${ }^{16}$, is undertaken to support both physical and digital libraries' role as equalizers of access to knowledge. Finally, further discussion is conducted to draw conclusions and support that laws could in the future turn ideal scenarios into realities.

\section{Towards a Universal Digital Library?}

The goal pursued by the Library of Alexandria was to get a copy of every book in the world. Today, technologies enable us to do the whole thing all over again. But why make it happen in one place, when we can make information available to people all over the world ${ }^{17}$ ?

Many years ago, some authors envisioned a time when everyone would access all information that is thought or known ${ }^{18}$. In the end of the $20^{\text {th }}$ century, others imagined an environment, where world's knowledge would be available to anyone with a computer and there would be a single global information space ${ }^{19}$. Last year, such proposals were brought back to the discussion table ${ }^{20}$.

After having digitized law and the news in the $1980 \mathrm{~s}^{21}$, we moved on to the next generation: the digital libraries of books and journals. Such libraries enabled scholars and students to save time and space and deepen their dialogue ${ }^{22}$, albeit they

legal, or technical barriers (including those of gaining access to the very Internet itself). So, "unimpeded access" should be regarded as broader than "open access".

16 The term "ethics" derives from the Greek word "ethos", meaning "way of living", and is a branch of philosophy that deals with human conduct and the behavior of individuals in society. See Capurro Rafael, Information ethos and information ethics, Ideas to take responsible action in the field of information, 1988. Available at http://www.capurro.de/informationsethos.htm (In German). As others have argued, ethics studies the rational justification for individuals' moral judgments and examines what is morally right or wrong, just or unjust, while setting rules of conduct. See Kaddu Sarah, Information Ethics: a student's perspective, International Review of Information Ethics Vol. 7, 2007, at p. 2. Available at http://www.i-r-i-e.net/inhalt/007/35-kaddu.pdf. Finally, some authors believe that ethics includes moral choices made by individuals in relation to the rest of the community, standards of acceptable behavior and rules that govern members of a profession. See Lynch Margaret, Ethical Issues in Electronic Information Systems, University of Colorado, 2000, available at https://www.colorado.edu/geography/gcraft/notes/ethics/ethics_f.html.

17 Brewster Kahle, Speech to the Library of Congress, "Digital Future" series, Dec. 13, 2004, broadcasted by C-Span TV (mentioning that "[...] This idea of universal access to all knowledge is within our grasp [...]"). Available at https://archive.org/details/cspan_brewster_kahle (at 10:20-11:40).

18 Wells Herbert George, World Brain, 1938, London, Methuen; Boyd W. Rayward, H.G. Wells's Idea of a World Brain: A Critical Reassessment, in Journal of the American Society for Information Science, 50(7), 1999, John Wiley \& Sons, Inc., pp. 557-573; Carr Nicholas, The Library of Utopia, April 25, 2012, MIT Technology Review, available at https://www.technologyreview.com/s/427628/the-library-of-utopia/.

${ }^{19}$ See Berners-Lee Tim, Weaving the Web: The original design and ultimate destiny of the World Wide Web by its inventor, HarperCollins, 1999, at p. 4. As some put it some years later, the perfect library would equalize access to fact and fiction by offering free copies of all books in the world. Vaidhyanathan Siva, The Anarchist in the Library: How the Clash Between Freedom and Control Is Hacking the Real World and Crashing the System, Basic Books, 2004, at p. 121; Between Pragmatism and Anarchism: The American Copyright Revolt since 1998, in M. Halbert (ed.): Free Culture and the Digital Library Symposium Proceedings, Atlanta, Georgia: MetaScholar Initiative at Emory University, 2005, pp. 13-42. Available at https://digital.library.unt.edu/ark:/67531/metadc97947/m2/1/high_res_d/FCDL-Proceedings-FINAL_0.pdf.

${ }^{20}$ See Brewster Kahle, Universal Access to All Knowledge, 2017, Lucile Kelling Henderson Lecture, UNC School of Information and Library Science, arguing that we should learn from the Library of Alexandria. Available at https://archive.org/details/2017UNCHendersonLectureByBrewsterKahle (at 44:25-44:45; also at 47:40, mentioning that "[...] Wikipedia is a great front door, now it's time to go to the rest of the house [...]").

${ }^{21}$ In the 1980s, full-text digital libraries related -mainly- to legal professions. For instance, Lexis/Nexis and Westlaw offered databases with regard to federal and state statutes, regulations, court decisions, law review articles etc. They also provided financial or news databases. See New York Times Co. v. Tasini, 533 U.S. 483 (2001). Available at https://supreme.justia.com/cases/federal/us/533/483/case.html; MacLachlan Lawrence Duncan, Gandy Dancers on the Web: How the Internet Has Raised the Bar on Lawyers' Professional Responsibility to Research and Know the Law, Georgetown Journal of Legal Ethics, Vol. 13, p. 607, 2000. Available at SSRN: https://ssrn.com/abstract=979541.

${ }^{22}$ For instance, JSTOR, conceived in 1994 by William Bowen, aimed to convert printed scholarly journals into digital form and store them in a centralized archive. Libraries, participating in JSTOR, could free physical space, reduce capital 
charged licenses for their services ${ }^{23}$. At the beginning of the $21^{\text {st }}$ century, digital libraries went one step further towards the creation of free-to-read collections of books that would be available to everyone over the Internet ${ }^{24}$. Namely, the Internet Archive included collections of e-books and Web pages ${ }^{25}$, while Amazon ${ }^{26}$ and Google ${ }^{27}$ built their own libraries to provide elegant platforms that enabled "digital patrons" to search through multiple pages or whole chapters.

But could we create a Universal Digital Library, which would offer unimpeded access to all stored knowledge ${ }^{28}$, based on existing models and tools?

Open-Source ${ }^{29}$ models and tools could enable works to be distributed free of charge in a commons-based peer ${ }^{30}$ production $^{31}$ that would be strongly supported by Open Archives ${ }^{32}$. Since we are systematically bad at understanding

and improve access to research. JSTOR currently provides more than ten million academic journal articles, fifty thousand books and two million primary source documents in seventy five disciplines. See https://www.jstor.org/.

${ }^{23}$ See -amongst others- Guthrie M. Kevin, JSTOR: The Development of a Cost-Driven, Value-Based Pricing Model, 1997. Available at https://files.eric.ed.gov/fulltext/ED414924.pdf.

24 Reddy Raj, StClair Gloriana, The Million Book Digital Library Project, available at http://www.rr.cs.cmu.edu/mbdl.htm or http://www.ulib.org/.

${ }^{25}$ See http://archive.org/web/; https://archive.org/details/millionbooks.

${ }^{26}$ See Lewis Robin, Amazon... From Earth's Biggest Bookstore To The Biggest Store on Earth?, The RobinReport, Jan. 24, 2012, available at http://www.therobinreport.com/amazon-from-earths-biggest-bookstore-to-the-biggest-store-on-earth/.

${ }^{27}$ In 2004, Google decided to copy all books in the world and build its own "Library of Alexandria". Wyatt Edward, New Google Service May Strain Old Ties in Bookselling, Oct. 8, 2004, available at

http://www.nytimes.com/2004/10/08/technology/new-google-service-may-strain-old-ties-in-bookselling.html. See also Authors Guild v. Google, Inc., No. 13-4829 (2d Cir. 2015);

https://www.authorsguild.org/wp-content/uploads/2008/10/Authors-Guild-v-Google-09202005.pdf; https://www.authorsguild.org/wp-content/uploads/2008/10/Settlement-Agreement.pdf.

${ }^{28}$ When each person can share all stored knowledge and instantly exchange new ideas, any field may advance at exponential rates. Vernor Vinge, Technological Singularity, Vision-21 Symposium, NASA Lewis Research Center \& the Ohio Aerospace Institute, March 30-31, 1993.

${ }^{29}$ Weber mentions three essential features of "the semiofficial Open Source Definition": source code must be distributed with the software or otherwise made available for no more than the cost of distribution; anyone may redistribute the software for free, without royalties or licensing fees to the author; anyone may modify the software or derive other software from it, and then distribute the modified software under the same terms. Weber Steven, The Success Of Open Source, Harvard University Press, 2004, at p. 5. See also the Open Source Definition provided by the Open Source Initiative. Available at https://opensource.org/osd-annotated.

${ }^{30}$ Peer-to-peer systems, whether digital or analog, have an end-to-end design (meaning all the "thinking" happens at the end point, e.g. a personal computer), are decentralized (in the sense that resources are spread out and flow easily) and antiauthoritarian (e.g. no one can turn the system off), are difficult to manage (for instance, removing content or individuals requires excessive effort), and are extensible (meaning they support open access to many). See Vaidhyanathan Siva, The Anarchist in the Library, id, at p. 17.

${ }^{31}$ Commons-based information production and peer production are structurally participatory, self-governing and definitely more dialogic than previous models. See Benkler Yochai, The Idea of Access to Knowledge and the Information Commons: Long-Term Trends and Basic Elements, in Access to Knowledge in the age of intellectual property, Gaëlle Krikorian \& Amy Kapczynski (eds), 2010, NY, Zone Books, pp. 217-236, at p. 229 (available at https://www.opensocietyfoundations.org/sites/default/files/age-of-intellectual-property-20101110.pdf).

${ }^{32}$ Danner A. Richard, Issues in the Preservation of Born-digital Scholarly Communications in Law, Law Library Journal, Vol. 96, No. 4, 2004, pp. 591-604, at p. 593 (with further references). Available at https://scholarship.law.duke.edu/cgi/viewcontent.cgi?referer=https://www.google.gr/\&httpsredir=1\&article=1549\&cont ext=faculty_scholarship\&sei-redir=1. Indeed, scientific scholarship is increasingly published online free of charge on open archives, which promote accessibility and affordability of such works. For interesting strategies to preserve the public domain in the digital environment, see Samuelson Pamela, Mapping the digital public domain: Threats and opportunities, Law and Contemporary Problems, Vol. 66, Winter/Spring 2003, pp. 147-171, at pp. 166-169. Available at https://scholarship.law.duke.edu/cgi/viewcontent.cgi?referer=https://www.google.gr/\&httpsredir=1\&article=1277\&cont 
-and predicting- the power of the so-called "open" or "commons-based" systems of development or innovation ${ }^{33}$ (and, thus, we tend to re-invent encyclopedia Britannica again and again -and again), let us provide a simple example to better understand the modus operandi of such systems. "English" could be regarded as an "open" or a "commons-based" system. Indeed, one does not have to pay to "use English" and we are all "running same version" -there is no version incompatibility ${ }^{34}$. Furthermore, no permission and no end-user-license agreement are required for a person to formulate a sentence, while she can produce new sentences, new words and this is how languages work ${ }^{35}$. So, for instance, use of open source software could be promoted, as it is freely modifiable and redistributable, while, at the same time, the standard open source license prohibits restricting access to or transformation of the code ${ }^{36}$. Independent Web publishing could also be taken into account, as it would guarantee not only equality of Internet speakers, who would engage in many-to-many communications, but also diversity of speech, accompanied by the removal of several intermediaries between authors and the audience ${ }^{37}$. Finally, lessons could be learnt from Wikis, as they aim to offer everyone free access to the sum ${ }^{38}$ of all human knowledge ${ }^{39}$.

So, based on open source tools, commons-based peer production and independent publishing and inspired by "Wikis' philosophy", the desirable Universal Digital Library could be constructed to include all information, from science and

ext=lcp.

${ }^{33}$ Boyle James, Keynote (June 16, 2006), CALI Conference for Law School Computing, Learning By Design and other Fallacies: What Behavioral Economics, Serendipity and Procrastination Can Teach Us About Educational Technology.

${ }^{34}$ One could argue that this may not be true between parents and children (but this is just an example to understand the basic concept).

${ }^{35}$ Other scholars have mentioned "gossip", "punk rock communities" or "religions" (like Judaism) as good examples of peer-to-peer systems, as they are "anarchistic", while they create new communities, close the gap between creators and consumers, democratize elements of cultural production, and demand a new set of theories. See Vaidhyanathan Siva, The Anarchist in the Library, id, at pp. xvi, xvii, 18 (where anarchy is regarded as "radical democracy"). Indeed, one could fairly argue that gossip is uncensored, unmediated, and unfiltered communication, and, thus, may be regarded as a peer-to-peer system.

${ }^{36}$ Lessig Lawrence, The Architecture of Innovation, Duke Law Journal, vol. 51, 2002, pp. 1783-1801. Available at: https://scholarship.law.duke.edu/dlj/vol51/iss6/2. See also Warr Hanadashisha, Open Source Digital Library Software: A Literature Review, id. For some basic definitions see Daley John, Insecure Software Is Eating the World: Promoting Cybersecurity in an Age of Ubiquitous Software-Embedded Systems, 2016, 19 Stanford Technology Law Review, pp. 533-546, at p. 539, defining "source code" as the human-readable representation of the set of instructions that control the operations of a computer. Available https://law.stanford.edu/publications/insecure-software-is-eating-the-world-promoting-cybersecurity-in-an-age-of-ubiqu itous-software-embedded-systems/.

${ }^{37}$ Travis Hannibal, Pirates of the Information Infrastructure: Blackstonian Copyright and the First Amendment, Berkeley Technology Law Journal, Vol. 15, Issue 2, 2000, pp. 777-864, at pp. 851-857. Available at https://scholarship.law.berkeley.edu/btlj/vol15/iss2/7/.

${ }^{38}$ See Mesgari Mostafa, Okoli Chitu, Mehdi Mohamad, Nielsen Finn Årup, Lanamäki Arto, "The sum of all human knowledge": A systematic review of scholarly research on the content of Wikipedia, in Journal of the American Society for Information Science and Technology, 2014, (postprint version available at

http://citeseerx.ist.psu.edu/viewdoc/download?doi=10.1.1.726.596\&rep=rep1\&type=pdf). See also Stone Brad, It's Like a Blog, But It's a Wiki, Newsweek, 31.10.2004, available at http://www.newsweek.com/its-blog-its-wiki-129317.

${ }^{39}$ Although wikis' reliability has been questioned, many of their articles are considered to be more informative and timely than corresponding articles in other encyclopedias. As some have argued, Wikipedia provides a "rich example" of a successful collaboration on an open source project that can achieve a highbrow quality. See Benkler Yochai, Coase's Penguin, or, Linux and The Nature of the Firm, The Yale Law Journal, Vol. 112, 2002, pp. 369-446, at p. 387. Available at http://digitalcommons.law.yale.edu/cgi/viewcontent.cgi?article=4061\&context=fss_papers. As Benkler argues, the culture of free software is the culture of science and the operative protocols of science are publication, peer-review and revision. See also Arazy Ofer, Morgan Wayne \& Patterson Raymond, Wisdom of the Crowds: Decentralized Knowledge Construction in Wikipedia, December 8, 2006, $16^{\text {th }}$ Annual Workshop on Information Technologies \& Systems (WITS), available at SSRN: https://ssrn.com/abstract=1025624 or http://dx.doi.org/10.2139/ssrn.1025624, who argue that crowd size and diversity explain Wikipedia's content quality. 
literature to opinions and entertainment ${ }^{40}$. While works of the public domain would be a good starting point, copyrighted works would be copied as well and, thus, existing laws with regard to reproduction would be an obstacle.

Copyright is a significant barrier to preserving cultural heritage ${ }^{41}$ in digital libraries ${ }^{42}$, as scanning of books -and digitization of other works- infringes the copyright owner's reproduction right ${ }^{43}$. So far, rightsholders have objected to innovative technologies ${ }^{44}$, while the very market has repeatedly influenced legislators ${ }^{45}$, on whom pressure has been put by lobbyists ${ }^{46}$. As some authors have aptly put it, firms seek new copyright rules so broad that they could conceivably outlaw even personal computers as possible tools for copying infringement ${ }^{47}$. It seems that, today, laws aim not to enhance sharing of learning and skills but to ensure that people will be prevented from knowing ${ }^{48}$, since current rules ${ }^{49}$ have

${ }^{40}$ Alper Joseph, Assembling the World's Biggest Library on Your Desktop, in Science, 18 Sep 1998, Vol. 281, Issue 5384, pp. 1784-1786, DOI: $10.1126 /$ science.281.5384.1784, available at

https://www.jstor.org/stable/2895759?seq=1\#page_scan_tab_contents.

41 "Cultural heritage" refers to all testaments to cultures, past and present, and contains within it an "onward transmission". If it is not recorded, it will not be transferred from generation to generation. See Gorman Michael, The Wrong Path and The Right Path: The role of libraries in access to, and preservation of, cultural heritage, in New Library World, Vol. 108, No. 11/12, 2007, pp. 479-489, at pp. 484, 486. Gorman argues that libraries are mainly concerned with messages, which constitute the human record, and only secondarily with the medium by means of which messages are transmitted. See Gorman Michael, id, at p. 482.

${ }^{42}$ See, amongst others, Eldred v. Ashcroft, 537 U.S. 186 (2003), No. 01-618. Argued October 9, 2002 - Decided January 15, 2003; President's Information Technology Advisory Committee, Digital Libraries: Universal Access To Human Knowledge, Panel on Digital Libraries, February 2001, available at https://www.nitrd.gov/pubs/pitac/pitac-dl-9feb01.pdf.

${ }^{43}$ However, Litman argues that "[...] the better view of the law is that the act of reading a work into a computer's random access memory is too transitory to create a reproduction [...]". See Litman Jessica, The Exclusive Right to Read, The Herbert Tenzer Memorial Conference: Copyright in the Twenty-First Century, The Role of the Copyright Office, 13 Cardozo Arts \& Ent. L. J. 29, 1994, available at http://www-personal.umich.edu/ jdlitman/papers/read.htm\#FN64.

${ }^{44}$ See, for example, Fortnightly Corp. v. United Artists Television, Inc., 392 U.S. 390 (1968); Teleprompter Corp. v. Columbia Broadcasting, 415 U.S. 394 (1974); Justice Scalia's dissenting opinion in case Am. Broad. Cos. v. Aereo, Inc., 573 U.S. (2014), available at https://supreme.justia.com/cases/federal/us/573/13-461/dissent4.html. See also Authors Guild v. Google, Inc., No. 13-4829 (2d Cir. 2015).

${ }^{45}$ For example, CATV's (Community Antenna Television) market influenced Congress and the Copyright Act of 1976 was passed to establish a compulsory copyright license system for cable (17 U.S.C. § 111(c), 1976). See -amongst othersCate H. Fred, Cable Television and the Compulsory Copyright License, Federal Communications Law Journal, Vol.42, 1990, pp. 192-238, at pp. 202-214, available at

https://www.repository.law.indiana.edu/cgi/viewcontent.cgi?article=1749\&context=facpub.

${ }^{46}$ Many scholars comment that firms play a leading role during law-making procedures. Namely, some academics argue that Disney put pressure on Congress to pass the Sonny Bono Copyright Term Extension Act. See Scheufen Marc, Copyright Versus Open Access, id, p. 20; Leveque Francois, Ménière Yann, The Economics of Patents and Copyright, Monograph, Berkeley Electronic Press, July 2004, available at SSRN: https://ssrn.com/abstract=642622, at p. 68; Corigan R. \& Rogers M., The economics of copyright, World Economics, Vol. 6, No. 3, 2005, pp. 53-174, at p. 164. The above Act was renamed by academics "Mickey Mouse Copyright Extension Act". See Stallman Richard, Free software Free society, id, at p. 141. In other cases, some mention that law was treated as a kind of contract between firms and note that industries were literally asked to draft the rules by which "they would live". See Boyle James, The Public Domain, Enclosing the Commons of the Mind, 2008, Yale University Press, at p. 56. See also Litman Jessica, Digital Copyright, Amherst: Prometheus, 2001, pp. 22-69; Netanel W. Neil, Why Has Copyright Expanded? Analysis and Critique, in New Directions in Copyright Law, Vol. 6, edited by Fiona Macmillan (Cheltenham: Edward Elgar, 2008), pp. 3-34.

${ }^{47}$ Brin David, The Transparent Society, Will technology Force Us to Choose Between Privacy and Freedom?, Basic Books, 1998, US, at p. 90.

${ }^{48}$ As some have argued, science should be an open field of knowledge. However, in practice, everything seems to be done to restrict access to scientific information and promote commercial profit over intellectual benefit. See Roger Tatoud, Gridlocking Knowledge, openDemocracy, July 12, 2002, available at https://www.opendemocracy.net/media-copyrightlaw/article_336.jsp.

${ }^{49}$ As many authors argue, current copyright laws are based on an analogue world that is far removed from the digitized environment. See Levin Marianne, Intellectual Property Rights in Transition - Legal Structures and Concepts in 
created a "virtually perpetual" copyright that inhibits the progress of knowledge ${ }^{50}$.

But in the traditional environment we used to be allowed to browse through a book before deciding whether to buy it, or photocopy an article to share with a friend, and it is extremely doubtful whether such actions, when undertaken in the digital environment ${ }^{51}$, are allowed ${ }^{52}$. Maybe, what we do not see today is that instead of the digital world becoming more like the real world, the real world is becoming more like the digital environment. It may seem awkward to talk about the Internet $^{53}$ as a "new technology" these days ${ }^{54}$, but it has undeniably changed the rules. Namely, reproduction is no longer an appropriate way to measure copyright infringement ${ }^{55}$, while users have become active participants in a brand new "bastard" ${ }^{56}$ culture. File-sharing is not only a vital element of communication but also an important tool used by

Adaptation to Technological Challenges towards an Intellectual Property System for the $21^{\text {st }}$ Century, 42 Scandinavian Stud. L. 83, 2002, pp. 83-93, at pp. 83, 84. Levin observes that we are experiencing an unprecedented commodification of research findings, where even components of human beings are eligible for patent protection (Levin Marianne, id, at $\mathrm{p}$. 85). As others have argued, copyright law reproduced the rules of the physical world into the digital reality and, thus, furthered the interests of the rightsholders while it completely ignored the needs of the users. See Gracz Katarzyna, Bridging the gaps between social and legal norms concerning protection of intellectual and artistic creations: On the crisis of Copyright Law in the Digital Era, The Journal of World Intellectual Property, Vol. 16, No. 1-2, 2013, pp. 39-57, at p. 41.

${ }^{50}$ Eldred $v$. Ashcroft, 537 U.S. 186 (2003), at 243, mentioning that "[...] The economic effect of this 20-year extension-the longest blanket extension since the Nation's founding-is to make the copyright term not limited, but virtually perpetual. Its primary legal effect is to grant the extended term not to authors, but to their heirs, estates, or corporate successors. And most importantly, its practical effect is not to promote, but to inhibit, the progress of "Science"-by which word the Framers meant learning or knowledge [...]".

${ }^{51}$ For example, a personal computer stores, retrieves, or copies data, while all Internet communications are generated by a combination of the above activities. The very act of storing or retrieving demands or involves copying, which in most cases is prohibited by law.

${ }^{52}$ As some scholars have argued, the regulation of reading or listening raises deep constitutional concerns; if the day ever comes when we have to apply for a license to listen or read, content producers will be cops and judges in matters of copyright. See, in general, Vaidhyanathan Siva, Copyrights and Copywrongs, The Rise of Intellectual Property and How it Threatens Creativity, New York, NYU Press, 2001, Project MUSE.

${ }^{53}$ Some authors have declared the Internet the most important human advancement since the printing press or even the most important discovery since fire. See, amongst others, Barlow P. John, A Declaration of the Independence of Cyberspace, Electronic Frontier Foundation, Feb. 9, 1996. To others, the Internet is a cynical cosmos, designed along cynical principles (i.e. "borderlessness", "unregulatability", peer-to-peer openness and peer-review accountability that also belong to realms of science and the academy) to serve cynical ends better than any others. See Vaidhyanathan Siva, The Anarchist in the Library, id, at pp. 26, 27, where the author brilliantly argues that Diogenes of Sinope was a hacker, expressing his freedom by masturbating in the marketplace; and nothing represents the overall nature of the Internet better than "masturbating in the marketplace". See also Branham Bracht Robert, Goulet-Caze Marie-Odile, The Cynics: The Cynic Movement in Antiquity and Its Legacy, Hellenistic Culture and Society, No. 23 (Berkley, University of California Press, 1996).

${ }^{54}$ Omer Tene, Privacy: The New Generations, in International Data Privacy Law, 2011, Vol. 1, No. 1, pp. 15-27, at p. 16.

${ }^{55}$ Litman Jessica, Revising Copyright Law for the Information Age, 75 Oregon Law Review, 19, 1996, at p. 37, available at http://www-personal.umich.edu/ jdlitman/papers/revising.htm. Given that, today, innumerous minors download a huge volume of copyrighted works, one could argue that we have to deal with a whole new generation of criminals. Indeed, youth has been recognized as the majority of unauthorized downloaders and uploaders. See Krawczyk Michał, Tyrowicz Joanna, Kukla-Gryz Anna \& Hardy Wojciech, Piracy is not theft! Is it just students who think so?, in Journal of Behavioral and Experimental Economics, Vol. 54, 2014, pp. 32-39, at p. 33 (with further references). As some had predicted, in the future new technology will allow government to solve $100 \%$ of all crimes, but the bad news is that we will realize that $100 \%$ of the population are criminals. See Adams Scott, The Dilbert Future: Thriving on Stupidity in the $21^{\text {st }}$ Century, NY, HarperCollins, 1997 (making the hilarious extrapolation that every human on the planet will land in jail, apart from the world's smartest person who, since she was too clever to get caught, has to, thereafter, bear the tax burden of supporting everyone else in prison, forever). See also Brin David, The Transparent Society, id, at p. 23.

${ }^{56}$ Mirko Tobias Schäfer, Bastard Culture! How user participation transforms cultural production, 2011, Amsterdam University Press, pp. 1-256, at p. 11, who uses the term "bastard" to describe a new culture where multiple participants and practices blend together. For limited protection that copyright may provide with regard to social networks, see Georgiades Eugenia, The limitation of copyright: sharing personal images on social networks, Sweet \& Maxwell and its 
individuals to understand themselves, their society and their place in the world ${ }^{57}$. However, people's participation in constructing culture is not only denied but also criminalized ${ }^{58}$ by laws ${ }^{59}$ that - to some- choke creativity ${ }^{60}$.

So, our approach -and proposal for a Universal Digital Library- needs to go further and think beyond laws (or perhaps just remember laws' original goals) to re-shape current conceptualization of copyright.

Ideas should freely spread from one to another over the world for the moral and mutual instruction of people and the improvement of their condition ${ }^{61}$. Knowledge should be regarded -not only as power but also- as a common property, created by and for people to communicate, advance learning and benefit culture ${ }^{62}$. Besides, the main goal of Intellectual Property laws was to stimulate creativity for the general public good ${ }^{63}$. It was to make sure that knowledge was openly shared, as quickly as possible, while profits were of secondary concern and were regarded as a mere vehicle to achieve the above goals ${ }^{64}$.

By thinking beyond the current regime and by remembering original goals of the above rules, proposals on the amendment (or even the abolition ${ }^{65}$ ) of copyright laws could be submitted to achieve the goals of a Universal Digital

Contributors, European Intellectual Property Review, 2018, Vol. 40, No. 4, pp. 230-242.

${ }^{57}$ Cantillon Sinead, Property for Free: An Analysis of Music and Copyright in the Digital Age, 11 Hibernian L.J. 35, 2012, pp. 35-62, at p. 39 (with further references). Cantillon argues that copyright is the most important corporate asset for the entertainment industry, while $90 \%$ of authors receive insufficient reward. See Cantillon Sinead, Property for Free, id, at pp. 52,56

${ }^{58}$ As Vaidhyanathan questioned some years ago "[...] What does it mean for the future of democracy when a nation prosecutes someone for opening up the electronic text of Aldous Huxley's Brave New World? [...]". See Vaidhyanathan Siva, The Anarchist in the Library, id, at p. x.

${ }^{59}$ For instance, the DMCA's (Digital Millennium Copyright Act) anti-circumvention provisions limit the ability to actively participate in the construction of meaning. See Jackson Matt, Using Technology to Circumvent the Law: The DMCA's Push to Privatize Copyright, Hastings Communications and Entertainment Law Journal, Vol. 23, No. 3, 2001, pp. 607-646, at p. 638. Available at https://repository.uchastings.edu/hastings_comm_ent_law_journal/vol23/iss3/5.

${ }^{60}$ See, in general, Lessig Lawrence, Free Culture: How big media uses technology and the law to lock down culture and control creativity, The Penguin Press, 2004. Available at http://www.free-culture.cc/freeculture.pdf.

${ }^{61}$ As Jefferson put it many years ago, this seems to have been "[...] peculiarly and benevolently designed by nature, when she made them, like fire, expansible over all space, without lessening their density in any point, and like the air in which we breathe, move, and have our physical being, incapable of confinement or exclusive appropriation. Inventions then cannot, in nature, be a subject of property [...]". See Thomas Jefferson to Isaac McPherson, 13 Aug. 1813, Writings 13:333-35, in The Founders' Constitution, Volume 3, Article 1, Section 8, Clause 8, Document 12, available at http://press-pubs.uchicago.edu/founders/documents/a1_8_8s12.html, The University of Chicago Press, The Writings of Thomas Jefferson, edited by Andrew A. Lipscomb and Albert Ellery Bergh, 20 vols, Washington: Thomas Jefferson Memorial Association, 1905.

${ }^{62}$ Swearingen C. Jan, Originality, Authenticity, Imitation and Plagiarism: Augustine's Chinese Cousins, in Lise Buranen \& Alice Myers Roy (eds), Perspectives on Plagiarism and Intellectual Property in a Postmodern World, 1999, State University of NY, at p. 21. See also Mazumder Anirban, Anomalies in Copyright Law, in The Journal of World Intellectual Property, 2006, Vol. 9, No. 6, pp. 654-672, at p. 655 (arguing that in some cultures precise imitation of the master is a must for several arts, such as folk music, dance or painting). Mazumder mentions that knowledge is not just power but also the source of profit in modern economies and that any attempt to regulate the access and use of information can be counterproductive. See Mazumder Anirban, id, at pp. 661-662.

${ }^{63}$ See Twentieth Century Music Corp. v. Aiken, 422 U.S. 151 (1975), at p. 422 (U.S. 156); Melamed Douglas, Picker Randal, Weiser Philip, Wood Diane, Antitrust Law and Trade Regulation, id, at p. 901.

${ }^{64}$ Brin David, The Transparent Society, id, at pp. 93-94 (mentioning that Intellectual Property law was originally meant to foster public disclosure and dissemination of new ideas). Stallman argues that copyright's role has been completely reversed: copyright law was set up to let authors restrict publishers for the sake of the general public, albeit digital technology has turned it into a system that lets publishers restrict the public in the name of the authors. See Stallman Richard, Let's Share, 30.05.2002, openDemocracy.net, available at https://www.opendemocracy.net/media-copyrightlaw/article_31.jsp.

${ }^{65}$ See, amongst others, Lessig Lawrence, The Future of Ideas: The fate of the commons in a connected world, NY, Random House, 2001, available at http://www.the-future-of-ideas.com/download/lessig_FOI.pdf. 
Library that would, in turn, guarantee unimpeded access to all knowledge.

So, a radical and, to some, extreme alternative to copyright could be to establish a regime, under which all intellectual products would remain non-owned ${ }^{66}$. To some, this "information socialism" ${ }^{97}$ could expand intellectual commons ${ }^{68}$ and foster creativity, while, at the same time, it would lead to a greater political and economic equality ${ }^{69}$. If this were the case, the utopian Universal Digital Library could be built without any legal obstacles.

But some might argue that this is far from simple and we are far from being there. Thereafter, a less straightforward alternative would be a registration system ${ }^{70}$, under which authors would be required to declare by a clear affirmative action their wish to protect their works. This could be strongly supported by current technologies ${ }^{71}$ : flexible mechanisms, which would better comply with the digital environment and today's uses of works, could be activated to build a more equitable, accessible and innovative world ${ }^{72}$. In such a scenario, flexible licenses would be the default. The ideal Universal Digital Library could, thus, make e.g. musical or scientific works available under open licenses that would foster creation and cultural diversity ${ }^{73}$. Free-of-charge access would be promoted and library resources could be free; there would be no registration fees to limit access or contribute to discrimination. Social networks ${ }^{74}$ could also be used to

${ }^{66}$ This would mean that products of human intellect would not be owned by individuals, firms, or governments as common property and ideas would be available to be used by anyone. See Martin Brian, Information liberation, Challenging the corruptions of information power, London: Freedom Press, 1998 (available at https://www.uow.edu.au/ bmartin/pubs/98il/ilall.html\#chapter\%2010). Martin mentions language and scientific knowledge as examples of non-owned intellectual products and points out that the most dynamic parts of science are those with the least secrecy and that turning knowledge into a commodity inhibits science.

${ }^{67}$ Spinello Richard \& Bottis Maria, A Defense of Intellectual Property Rights, Edward Elgar, UK, USA, 2009, at p. 6 (with further references).

${ }^{68}$ Non-owned public spaces have enormous social value, but on the Internet everything is owned by some private entity. Even these websites independently run by natural persons are hosted on some private server. So, there is no commons on the Internet. See Schneier Bruce, Data and Goliath, The Hidden Battles to Collect Your Data and Control Your World, W.W. Norton \& Company, NY, London, 2015, at pp. 221-222, arguing that we need places to speak, converse, gather, or protest.

${ }^{69}$ Spinello Richard \& Bottis Maria, A Defense of Intellectual Property Rights, id; Martin Brian, Information liberation, id.

${ }^{70}$ Sprigman Christopher Jon, Reform(aliz)ing Copyright, Stanford Law Review, Vol. 57, 2004, pp. 485-568 (Stanford Public Law Working Paper No. 88, available at SSRN: https://ssrn.com/abstract=578502), at p. 556.

${ }^{71}$ Brin David, The Transparent Society, id, at pp. 103, 105.

${ }^{72}$ Besides, flexible models, such as Creative Commons (CC), already exist. CC licenses aim to authorize use of copyrighted works for purposes that would otherwise constitute infringement. See https://creativecommons.org/licenses/. See also Scharf Nick, Creative Commons-ense? An analysis of tensions between copyright law and Creative Commons, Journal of Intellectual Property Law and Practice, 2017, Vol. 12, No. 5, pp. 376-383, p. 376 (see also at p. 380 mentioning that, although subject to Crown Copyright, data.gov.uk has a significant CC endorsement, since the content's licenses are compatible with CC Attribution License 4.0). For the important role that private law can play in the digital environment, see Bowrey Kathy, Law and Internet Cultures, 2005, Cambridge University Press, at p. 164.

${ }^{73}$ Some platforms do share music that is specifically designed for use in public libraries. This dissemination of free music seems to enable librarians to contribute to artistic creation. See, for example, French collaborative platform Ziklibrenbib (http://www.acim.asso.fr/ziklibrenbib/).

${ }^{74}$ In the social context, a network consists of a set of individuals and of the links among them ("[...] Links between pairs of individuals might represent a wide range of connections, including such activities as friendship, advice seeking, informational communication, and material transfers [...]"). See Krackhardt David \& Stern N. Robert, Informal Networks and Organizational Crises: An Experimental Simulation, 51 Social Psych. Q. 123, 127 (1988). Social networking sites are a kind of an online service, which aims to create social relations between people, who share common interests and activities. Information sharing with one's public or private contacts is the primary function of the above networks. See Krasnova H., Spiekermann S., Koroleva K., \& Hildebrand T., Online social networks: why we disclose, Journal of Information Technology, 25(2), 2010 109-125, DOI:10.1057/JIT.2010.6. Available at SSRN: https://ssrn.com/abstract=2050898. 
share links to content or report new uploads ${ }^{75}$.

But only mathematicians can prove things using pen and paper. The rest of us have to take ideas pragmatically into the real world and see what works ${ }^{76}$. In fact, it is extremely doubtful whether, for example, artists would choose to teach their art, instead of selling $\mathrm{it}^{77}$. And since such -not that dangerous- utopias would most probably not "find" their lobbyist ${ }^{78}$ let us move on to further -more doable- proposals, based on Information Ethics, to support the potential of today's physical and digital libraries as equalizers of access to information.

\section{Libraries' Potential to Promote Information Ethics and Bridge the Digital Divide}

"Information ethics"79 deals with moral dilemmas and ethical conflicts arising from interactions between humans and information (e.g. creation or organization), Information and Communication Technologies (ICT), and information systems ${ }^{80}$. It is concerned (amongst others) with choices and decisions that have to be made in several topics, including access, ownership, privacy, security or community ${ }^{81}$.

As some authors have argued, information professionals should take responsibility and action for information policies in both professional and public settings ${ }^{82}$. In this context, human freedom should play a key role as a principle of openness of human beings to each other and to the world ${ }^{83}$. Thereafter, technology and humans could be united in harmony to ensure that the benefits of information technology are, not only distributed equitably but also, used by people to shape their own lives ${ }^{84}$.

75 Gisolfi Peter, New trends that define the $21^{\text {st }}$-Century-Library, Advances in Library Administration, pp. 173-195 (published online: 16 Jun 2015; https://doi.org/10.1108/S0732-067120150000033005), at p. 183.

76 Brin David, The Transparent Society, id, at p. 18.

77 With regard to major recording labels, they perform four basic tasks: production, distribution, price fixing, and gate-keeping (Vaidhyanathan Siva, The Anarchist in the Library, id, at p. 48). But bands, today, can use home computers to record music, put up their websites, and give away MP3s on peer-to-peer systems. Since they can -and do- make money through live performances, commons-based production and distribution may not seem so hard. Besides, music distribution has been all about "decorporatization" and "deregulation", while music corporations no longer control the flow, the prices, or the terms of access. Vaidhyanathan Siva, The Anarchist in the Library, id, at p. 106.

${ }^{78}$ Lessig Lawrence, Free Culture, Jan. 31, 2008, Speech at Stanford University (mentioning that the reason why copyright term was extended was that Mickey Mouse had a lobbyist, whereas the public domain did not).

${ }^{79}$ Information ethics has grown out of the interaction between traditions of librarianship and new technologies. Respect for privacy, defense of intellectual freedom, and devotion to collections were some of the main concerns of librarianship before the emergence of computers. See Asheim Lester, Not censorship but selection, Wilson Library Bulletin, September 1953, pp. 63-67, available at http://www.ala.org/advocacy/intfreedom/NotCensorshipButSelection.

${ }^{80}$ Robert Hauptman was the first to use the term "Information Ethics". Hauptman Robert, Ethical Challenges in Librarianship, Phoenix, AZ, Oryx Press, 1988, p. 3; Froehlich Thomas, A brief history of information ethics, bid, textos universitaris de biblioteconomia i documentació, número 13, 2004, Facultat de Biblioteconomia i Documentació, Universitat de Barcelona (available at http://bid.ub.edu/13froel2.htm).

${ }^{81}$ Smith Martha, Information ethics, id, at p. 32. As Smith aptly puts it, if ethics aims to study how to think with regard to ordering human life and if technology relates to tools and practices to advance human aims, then ICT and ethics must dance together ("even if badly"). Smith Martha, id, at p. 40.

${ }^{82}$ Capurro Rafael, Information ethos and information ethics, id.

${ }^{83}$ Capurro Rafael, Moral Issues in Information Science, first published as: Report TRITA-LIB-6024 (Royal Institute of Technology Library, Stockholm, Sweden) 1985, also published in Journal of information science, 11, 1985, pp. 113-123 (available at http://www.capurro.de/moral.htm). Capurro speaks of the concept of "specialized information" that includes all kinds of scientific, technical, economic and societal knowledge.

${ }^{84}$ Capurro Rafael, Information Technology and Technologies of the Self, in Annual Meeting of the American Society for Information Science (ASIS), Pittsburgh, October 25-29, 1992, also in the Journal of Information Ethics, 1996, Vol. 5, No. 2, pp. 19-28. Available at http://www.capurro.de/self.htm. Capurro uses the term "technologies of the self" to approach the ethical goal of uniting nature, man and technology in harmony. Others have used the term "technological self" to refer to a human self constructed by technologies and practices of societies. See Margolis Zoseph, The technological self, in E. E Byrne and J. C. Pitt (eds), Philosophy and Technology: Technological Transformation: Contextual and Conceptual Implications, Vol. 5, Kluwer Academic, Dordrecht, The Netherlands, 1989, pp. 1-15; Hoffmann Anna Lauren, Privacy, Intellectual Freedom, and Self-Respect: Technological and Philosophical Lessons for Libraries, in Perspectives on 
So, could technologies be used to bridge the gap between the information rich and the information poor, and fight the oligarchic control of information resources ${ }^{85}$ ?

Digital divide refers to gaps between ICT haves and have-nots ${ }^{86}$, which include differences with regard to access to information, access to appropriate ICT hardware and software, literacy rates, and ICT skill-sets ${ }^{87}$. The main problem can be regarded in terms of inequality concerning a gap in meaningful access to ICT. This requires not only availability of technology but also the ability to use it -for socially useful purposes and- to economic and cultural advantage ${ }^{88}$.

In this context, access could be not only understood in a way to go beyond simple network connection but also regarded as an important tool that promotes human rights, whose enjoyment may be affected by the digital divide ${ }^{89}$. Indeed, human rights, such as the right to free speech or education (to name but a few), are facilitated by Internet access in ways that exceed capacities of previous ICTs. Hence, many authors have proposed the recognition of -meaningful- Internet access itself as a fundamental human right ${ }^{90}$, which is necessary to survive and live a full life ${ }^{91}$. So, access to information could

Libraries as Institutions of Human Rights and Social Justice (published online: 26 Feb 2016, pp. 49-69, available at https://doi.org/10.1108/S0065-283020160000041003), at pp. 50-56. Hoffmann focuses on the importance of self-respect for the realization of social justice and argues that libraries can be regarded as sites for self-respect.

${ }^{85}$ Capurro Rafael, Towards an information ecology, Contribution to the NORDINFO International seminar "Information and Quality", Royal School of Librarianship, Copenhagen, 23-25 August 1989. Proceedings: I. Wormell (ed.): Information Quality. Definitions and Dimensions. London, Taylor Graham 1990, pp. 122-139. Available at http://www.capurro.de/nordinf.htm.

${ }^{86}$ See Russell E. Susan, Libraries' role in equalizing access to information, Library Management, Vol. 30 Issue: 1/2, 2009, pp. 69-76. Available at https://doi.org/10.1108/01435120910927538. Russell studies the gap between those who have access to the latest information technologies and those who do not, and points out that the digital divide may be measured by computer ownership and internet accessibility (see at p. 69, with further references to Katsinas S. G., Moeck Patricia, The Digital Divide and Rural Community Colleges: Problems and Prospects, March 2002, Community College Journal of Research and Practice, 26(3), pp. 207-224, DOI10.1080/106689202317245419).

${ }^{87}$ Himma Kenneth Einar, Bottis Maria, Digital Technologies and the obligation to alleviate poverty: the digital divide, information gap and two forms of poverty, chapter 26, in Ethics and Emerging Technologies, Ronald Sandler editions, Palgave Mcmillan, 2014, pp. 333-346, at p. 333. Available at https://bottis.ihrc.gr/gr/publications/2014/.

${ }^{88}$ Himma Kenneth Einar, Bottis Maria, id, at pp. 334-335, 342-346, who aptly observe that one "cannot eat" ICTs, Internet access, or information; that physical infrastructure is needed to enable people's access and participation in the online economy; and that people should have the ability to use ICTs to produce an output that is "ultimately marketable in a global economy".

${ }^{89}$ Given that many forms of digital divides still remain between and within nations and people, institutions have recognized the need to bridge them and have affirmed the importance to apply a human rights-based approach in providing and expanding access to the Internet. See Resolution "The promotion, protection and enjoyment of human rights on the Internet" of the Human Rights Council of the United Nations (General Assembly), Promotion and protection of all human rights, civil, political, economic, social and cultural rights, including the right to development, A/HRC/32/L.20, Thirty-second session, Agenda item 3, 27 June 2016, available at http://thehill.com/sites/default/files/a_hrc_32_1.20_english-or-30-june.pdf.

${ }^{9090}$ La Rue Frank, Report of the Special Rapporteur on the promotion and protection of the right to freedom of opinion and expression, Human Rights Council, Seventeenth session (May 16, 2011), Agenda item 3, "Promotion and protection of all human rights, civil, political, economic, social and cultural rights, including the right to development", United Nations (General Assembly), A/HRC/17/27, at par. 21, mentioning that "[...] By explicitly providing that everyone has the right to express him or herself through any media, the Special Rapporteur underscores that article 19 of the Universal Declaration of Human Rights and the Covenant was drafted with foresight to include and to accommodate future technological developments through which individuals can exercise their right to freedom of expression. Hence, the framework of international human rights law remains relevant today and equally applicable to new communication technologies such as the Internet [...]". Available at http://www2.ohchr.org/english/bodies/hrcouncil/docs/17session/A.HRC.17.27_en.pdf.

${ }^{91}$ Petri Claire, Rural Libraries and the Human Right to Internet Access, in Rural and Small Public Libraries: Challenges and Opportunities (published online: 03 Nov 2017, pp. 13-35), at p. 21. Available at

https://doi.org/10.1108/S0065-283020170000043002. 
be treated (or even defined ${ }^{92}$ ) as a freedom and an opportunity to connect to, make use of, and benefit from the Internet and the information available on $\mathrm{it}^{93}$.

And how could libraries equalize this access and bridge the emerging gaps?

A basic plan could be to increase the availability of public access computers. But, since our approach calls for an effective use, information literacy ${ }^{94}$ skills could be, simultaneously, developed through software and computer programs. Such accessibility and training would very likely enable libraries to act as "equalizers" that would focus on the relevant community's unique requirements.

To better apply the above plan, libraries could convert several of their physical materials to digital format. Space could, hence, be utilized to welcome more Internet-equipped computers. Indeed, some libraries not only have moved towards this direction but have also undertaken initiatives to provide innovative "laptop-borrowing" services and make such computers available for "checkout" 95 . Furthermore, "training classes" could be introduced to make use of technologies more meaningful and meet users' needs. Such classes would very likely teach the audience how to use e.g. software programs $^{96}$ or how to conduct online searches, and could also introduce "Ethics" as a new subject in the above teaching sessions $^{97}$.

Libraries could also prove their potential as a community cultural centre and welcome various programs, including not only conferences or lectures but films, concerts, exhibitions or even dramatic performances ${ }^{98}$ as well. Thus, parts in a

92 Mathiesen Kay, Facets of access: A conceptual and standard threats analysis, in iConference 2014 Proceedings, 605-611, at p. 607 (doi:10.9776/14265), available at https://www.ideals.illinois.edu/bitstream/handle/2142/47410/265_ready.pdf?sequence=2\&isAllowed=y.

93 To some, there are several aspects of access to the Internet: physical access that involves simply connecting to the Internet; intellectual access, which refers to knowing how to use the Internet, and understanding the information received, and; social access that deals with the groups one may identify with and the values and norms these groups support. See Burnett Gary, Jaeger T. Paul, Thompson M. Kim, Normative behavior and information: The social aspects of information access, in Library \& Information Science Research, Volume 30, Issue 1, March 2008, pp. 56-66, at pp. 57-58 (https://doi.org/10.1016/j.lisr.2007.07.003).

${ }^{94}$ With regard to literacy, some authors have proposed to move on to a higher level and change basic education and literacy from the traditional "3Rs" (i.e. Reading, Writing, and Arithmetic) to "LNCI", a standard that includes Literacy (i.e. reading and writing), Numeracy (i.e. working with numbers), Communicacy (i.e. effective communication), and Innovativeness/Initiative. See OleKambainei Emmanuel, Sintim-Misa Mavis Ampah, Info-communication for Development in Africa, The African Connection Initiative, in Joseph O. Okpaku (ed.), Information and Communication Technologies for African Development. An Assessment of Progress and Challenges Ahead. New York, 2003, pp. 151-173; Capurro Rafael, Information ethics for and from Africa, Keynote address at the African Information Ethics Conference Pretoria (South Africa), $5^{\text {th }}$ to $7^{\text {th }}$ February 2007, in the International Review of Information Ethics (IRIE), 2007, reprinted in Journal of the American Society for Information Science and Technology, 59 (7), pp. 1-9, 2008. Available at http://www.capurro.de/africa.html. Capurro, calling for a broader perspective, points out that (African) information ethics is not only about access and use of technology: what we are dealing with is not a technical problem but a problem of "social exclusion, manipulation, exploitation, and annihilation of human beings".

95 See, for instance, the University of Oklahoma libraries' website (https://libraries.ou.edu/content/laptop-computer-borrowing). Under the University's policies, laptops can be borrowed for up to three hours. The University's building has also wireless access to serve students, who own a laptop but do not have Internet access.

${ }^{96}$ For example, Norman Public Library of Oklahoma provides both computer-classes and one-to-one assistance. See http://pioneerlibrarysystem.org/hometowns/norman-central.

${ }^{97}$ Schöpfel Joachim, Open Access, Privacy, and Human Rights: A Case Study on Ethics in Library and Information Sciences Education, in Perspectives on Libraries as Institutions of Human Rights and Social Justice, Advances in Librarianship, 2016, vol. 41 (published online: 26 Feb 2016), pp. 349-371 at p. 370, where it is mentioned that students do not learn ethics as they learn XML or a foreign language (available at

https://doi.org/10.1108/S0065-283020160000041015). Schöpfel suggests that free "civil digital workplaces" could also be created to fight digital divide and support citizens' equality with regard to information technology. Schöpfel Joachim, id, at p. 360.

${ }^{98}$ For example, Bronxville Public Library (New York) is "not just about books". It is also a cultural center that presents concerts, lectures, poetry readings, art exhibitions, films, or special programs for teens. See 
library could be used to encourage people to participate in events, talk and, hence, connect with each other, and share their experience and knowledge. By encouraging such interaction the idea and the sense of the community could be enhanced ${ }^{99}$.

To sum up, making public access to Internet-equipped computers available and introducing training classes, which would include not only "how-to-use-technologies" lectures but an "independent subject" concerning Information Ethics as well, could constitute a good starting point. Thereafter, libraries could act as community cultural centers and, thus, present several events to encourage peoples' interaction and promote the idea of the community. This way, libraries would move from their previous "shhhh-model", which discouraged -talking and- interaction, towards a new "community-based-model" that could very well bridge gaps between haves and have-nots, and minimize or even set aside differences with regard to access to information and appropriate ICTs.

\section{Discussion}

It is the very tradition of libraries that unimpeded and equitable access to information is an important element of functioning democratic societies ${ }^{100}$, while, as places where communities get constructed ${ }^{101}$, libraries have always been promoting intellectual freedom ${ }^{102}$. The very philosophy for Web development and the very goal of the Internet is to empower creativity, democratize production and celebrate the individual with the necessary attention drawn to mass collaboration $^{103}$. And it is true that, so far, we have witnessed innumerous economic and social benefits that new technologies not only promise but also do create in multiple fields ${ }^{104}$.

So, the creation of an ideal Universal Digital Library could be proposed to make all knowledge available and enable people to exercise their fundamental right to receive information. This scenario could be (inspired by and) based on current models of commons-based information production and peer production. And, today, we certainly have the technologies to render this idea a realistic act of benevolence and "a-piece-of-cake-task" thanks to existing systems. However, legal obstacles seem to turn such scenarios into a utopia that romantic authors may only dream of.

But culture is not a fixed condition; it is the product of interaction and its toughness and resiliency are determined by its ability to react creatively to the realities of new situations, rather than an ability to withstand change ${ }^{105}$.

http://bronxvillelibrary.org/lets/attend/. Darien Library in Darien (Connecticut) also uses "community rooms" for lectures, concerts or Friday night movies. See https://www.darienlibrary.org/events/calendar/adults/.

${ }^{99}$ For instance, the children's room at the Byram Shubert Library in Greenwich welcomes active users and encourages them to engage with each other. See https://www.greenwichlibrary.org/byram-shubert/; https://www.greenwichlibrary.org/children/.

${ }^{100}$ See, in general, Mc Colvin R. Lionel, The Chance to Read: Public Libraries in the World Today, 1956, Phoenix House Limited.

${ }^{101}$ Wiegand Wayne, Broadening Our Perspectives, The Library Quarterly, Information, Community, Policy, Volume 73, Number 1, 2003, The University of Chicago Press, pp. v-x, at p. viii.

102 Blitz Marc Jonathan, Constitutional Safeguards for Silent Experiments in Living: Libraries, the Right to Read, and a First Amendment Theory for an Unaccompanied Right to Receive Information, University of Missouri-Kansas City Law Review, 2006, Vol. 74, No. 4, pp. 799-882 (available at SSRN: https://ssrn.com/abstract=922335); Morgan Candace, Intellectual freedom: An enduring and all-embracing concept, in Intellectual freedom manual, 2006, $7^{\text {th }}$ Edition, Office for Intellectual Freedom, American Library Association, pp. 3-13, at pp. 3, 8.

${ }^{103}$ Zimmer Michael, The externalities of Search 2.0: The Emerging Privacy Threats When The Drive For The Perfect Search Engine Meets Web 2.0, 2008, First Monday, 13(3), available at

http://firstmonday.org/ojs/index.php/fm/article/view/2136/1944\#author.

${ }^{104}$ Indeed, thanks to new technologies crucial objectives have been achieved in fields of health care, education, or commerce. See Prins Corien, Property and Privacy: European Perspectives and the Commodification of our Identity, in L. Guibault and P.B. Hugenholtz (eds), The Future of the Public Domain, id, pp. 223-258, at pp. 226-230. See also Chang Junli, Zhu Xuezhong, Bioinformatics Databases: Intellectual Property Strategy, in Journal of Intellectual Property Rights, Vol. 15, Nov. 2015, pp. 447-454, at pp. 447, 449, who focus on the importance of bioinformatics (i.e. the science of information generation, transmission, receipt, and interpretation in biological systems) and argue that databases -when they consist of gene related data- should be put in the public domain.

${ }^{105}$ Levine W. Lawrence, Black Culture and Black Consciousness: Afro-American Folk Thought From Slavery To Freedom, New York, Oxford University Press, 1977, at p. 5, where it is mentioned that culture's ability to withstand change may be a sign of stagnation. 
In this context, culture is a process. But so is law. Culture should be allowed to change. And so should law be. In fact, legal knowledge is a process, not a corpus. It is strategic and negotiable ${ }^{106}$. Courts require truth within given times, meaning the best kind of legal point is the one that works and gets the job done persuasively and efficiently ${ }^{107}$. Law facilitates the flow of information from the governing to the governed, but also allows information to flow from the governed to the governing, incorporating new data from legal disputes ${ }^{108}$. The life of law is not logic, but experience, the felt necessities of the time and the prevalent moral and political theories, the intuitions of public policy, or even the "prejudices that judges share with their fellow-men" ${ }^{\prime 109}$. Law, as a social process, and legal practice, as a productive power of creativity that is used to satisfy needs, produce social norms ${ }^{110}$, imposing purpose over texts, data, or tradition ${ }^{111}$.

So, laws might someday encourage policies to build information regulation systems that reflect users' needs, instead of Disney's. Laws might someday create no (or at least low) barriers of entry to creative processes and cheap access to cultural materials through networks, libraries, universities, or any other institution built for sharing. Maybe, this same day, policies about who gets to own networks or about how long should copyright protection last may be subject to public debate, instead of being dictated by lobbyists. Perhaps, that day, lawmakers might understand the way culture works and grows. And the truth is it works best when content is cheap and easily distributed. It would be hard to name a cultural development that made a difference and that was not, at the same time, about communities sharing their ideas.

And if no lobbyist appears to submit such proposals, let us remember that, when drums became illegal in the American South to stifle communication across distances ${ }^{112}$, slaveholders outlawed the tools, but they never stopped the beat.

Perhaps, to some, the above proposals might not work in practice, but to others current copyright rules are creating a whole generation of thieves and terrorists ${ }^{113}$. Although it has been argued that without copyright (or without the alleged financial incentives to create), humanity would face the worst-case scenario of a cultural Dark Age, albeit, the "property talk instrument" could be regarded as a closed-system ideology that hopes to shut conversation down; who could argue for "theft"? So, what we probably need is an open and balanced discussion on openness and enclosure, protocols ${ }^{114}$ and

${ }^{106}$ Morison John \& Leith Philip, The Barrister's World -and the nature of law, Open University Press, Buckingham, 1992, at p. 195. Available at

https://www.researchgate.net/publication/301350373_The_Barrister's_World_And_the_Nature_of_Law.

${ }^{107}$ Morison John \& Leith Philip, The Barrister's World -and the nature of law, id, at p. 95.

${ }^{108}$ McGinnis John, Wasick Steven, Law's Algorithm, Florida Law Review, 2014, Vol. 66 No. 12/22, pp. 991-1050, at p. 993. Available at https://papers.ssrn.com/sol3/papers.cfm?abstract_id=2130085. McGinnis and Wasick argue that the very nature of legal production depends on technology of its age and mention Greek democracy as an example. See McGinnis John, Wasick Steven, id, at p. 1000 (citing Callister Douglas Paul, Law's Box: Law, Jurisprudence and the Information Ecosphere, University of Missouri-Kansas, City Law Review, 2005, Vol. 74, pp. 263-334, at p. 276, who mentions that "[...] publication of law is essential to Greek democracy, and failure to do so is equated with tyranny [...]". Available at SSRN: https://ssrn.com/abstract=703062).

109 Holmes Wendell Oliver, The Common Law, Project Gutenberg, 2000 (originally published by The Lawbook Exchange, Ltd. in 1881), at p. 1, available at http://www.gutenberg.org/files/2449/2449-h/2449-h.htm.

${ }^{110}$ Adam Harkens Adams, The ghost in the legal machine: Algorithmic governmentality, economy, and the practice of law, Journal of Information, Communication and Ethics in Society, 2018, Vol. 16 Issue 1, pp. 16-31, at p. 27 (https://doi.org/10.1108/JICES-09-2016-0038).

${ }^{111}$ Dworkin Ronald, Law's Empire, 1986, Harvard University Press, at p. 228, available at http://www.filosoficas.unam.mx/ cruzparc/empire.pdf.

${ }^{112}$ Eileen Southern, The Music of Black Americans: A History, $2^{\text {nd }}$ Edition, New York, Norton, 1983; Howard Dodson, America's Cultural Roots Traced to Enslaved African Ancestors, National Geographic, February 5, 2003

(https://news.nationalgeographic.com/news/2003/02/0205_030205_jubilee4_2.html); DJ Zhao, No drums allowed: Afro rhythmic mutations in America, August 1, 2014, ThisisAfrica

(https://thisisafrica.me/lifestyle/drums-allowed-afro-rhythmic-mutations-america/); Article 36 of the Slave Code of South Carolina (1740), available at

http://www.duhaime.org/LawMuseum/LawArticle-1501/1740-Slave-Code-of-South-Carolina-Articles-34-37.aspx.

${ }^{113}$ Lessig Lawrence, Free Culture: How big media uses technology and the law to lock down culture and control creativity, id, at pp. 10, 18; Krikorian Gaëlle, Free-Trade Agreements and Neoliberalism: How to Derail the Political Rationales that Impose Strong Intellectual Property Protection, in Access to Knowledge in the age of intellectual property, Gaëlle Krikorian \& Amy Kapczynski (eds), id, pp. 293-328, at p. 307. 
controls, or distribution and centralization. But what we have, so far, had were nasty battles among competing interests ${ }^{115}$.

In any case, the era when these laws will be re-conceptualized -to truly benefit "learning and knowledge", i.e. the good-old-fashioned meaning of "science", rather than granting rights to authors' heirs, estates, or corporate successors ${ }^{116}$ may not come anytime soon. Thereafter, what could be more realistic and achievable today would be initiatives focused on information ethics to equalize access to information and knowledge. And such acts could, indeed, be undertaken by the very bodies, which are active in the fields of culture. Both physical and digital libraries could very well perform their role as equalizers of knowledge and community cultural centers and, hence, make public access to Internet-equipped computers available, encourage interaction, and promote the idea of the community. This way community-based-models could be implemented to bridge existing gaps and abolish current differences.

The heart of this paper's argument is that there is a strong need for a universally accessible collection of "the sum of all knowledge" in restrictions-free formats that would ensure that information would be free, rather than locked up behind corporate pay-walls. This -technologically achievable- idea would be a moral act to address the access to knowledge issues. But since acts of benevolence do not happen that frequently these days, a more copyright-friendly approach could be brought to the discussion table to focus on equality and achieve fair distribution of information. At least, this way, information would flow, creators would be encouraged and we would all get to share in whatever is going on.

\section{Copyrights}

Copyright for this article is retained by the author(s), with first publication rights granted to the journal.

This is an open-access article distributed under the terms and conditions of the Creative Commons Attribution license (http://creativecommons.org/licenses/by/4.0/).

${ }^{114}$ As some have aptly observed, a protocol is a handshake, a "way for different actors to agree on rules of engagement, habits, traditions, or guidelines". See Vaidhyanathan Siva, The Anarchist in the Library, id, at p. 32.

115 And in such battles, one side usually has more expensive lawyers. See, for instance, Letter from Matthew J. Oppenheim to Professor Edward Felton, April 9, 2001, available at http://sip.cs.princeton.edu/sdmi/riaaletter.html.

${ }^{116}$ Eldred v. Ashcroft, 537 U.S. 186 (2003), id, at p. 243. 